\title{
ЭФФЕКТИВНОСТЬ ЖЕЛЕЗО- И КОБАЛЬТСОДЕРЖАЩИХ ХИМИЧЕСКИХ МОДИФИКАТОРОВ ПРИ ОПРЕДЕЛЕНИИ Аs, Нg и Сd В МОРСКОЙ ВОДЕ МЕТОДОМ ВЫСОКОРАЗРЕШАЮЩЕЙ АТОМНО-АБСОРБЦИОННОЙ СПЕКТРОМЕТРИИ С ИСТОЧНИКОМ СПЛОШНОГО СПЕКТРА И ГРАФИТОВОЙ ПЕЧЬЮ
}

Бурылин М.Ю., Галай Е.Ф., Лизун А.Ю., Баштовая А.С. ФГБОУ ВО «Кубанский государственный университет», Краснодар, Россия galaie@mail.ru

DOI: 10.26902/ASFE-11_147

Морская вода имеет важное значение в жизнедеятельности человека. Повышение предельно допустимых концентраций таких элементов как мышьяк, кадмий и ртуть в морских водах может оказывать негативное воздействие на организмы человека и обитателей морской среды. Поэтому особое внимание уделяется контролю содержания токсичных элементов в морской воде и проводится постоянный мониторинг данного объекта.

Одним из распространённых методов анализа является электротермическая атомноабсорбционная спектрометрия (ЭТААС), характеризующийся высокой чувствительностью и селективностью. Однако прямые определения в морской воде затруднительно из-за очень низкой концентрации токсичных элементов и высокого содержания матрицы. Решение этой проблемы возможно с использованием химических модификаторов (XM) и высокоэффективной системы коррекции неселективного поглощения метода высокоразрешающей атомно-абсорбционной спектрометрии с источником сплошного спектра (ВР-ААС-ИСС) и графитовой печью (ГП).

Целью данной работы являлось разработать условия определения легколетучих элементов (As, $\mathrm{Cd}, \mathrm{Hg}$ ) в морской воде методом ВР-ААС-ИСС в присутствии железо- и кобальтсодержащих ХМ на основе активированного угля [1,2]. Достижение поставленной цели позволит исключить применение наиболее распространенных XM на основе благородных металлов (Pd и Ir).

В ходе выполнения работы достигнуты минимально допустимые разбавления пробы для корректировки неселективного поглощения: двукратное для определения кадмия и ртути, пятикратное - для мышьяка. Определены оптимальные температуры стадии пиролиза/атомизации $\left({ }^{\circ} \mathrm{C}\right)$ при анализе проб воды в присутствии используемых XМ: 600/1200 для Cd, 1200/2000 для As, 200/600 для $\mathrm{Hg}$.

Модификаторы апробированы по методу введено-найдено с использованием проб морской воды, отобранной в акватории охотского моря. Пределы обнаружения и определения составили (мкг/л) 1,2 и 4,0 для As, 2,1 и 7,0 для $\mathrm{Hg}, 0,02$ и 0,07 для Сd соответственно.

\section{Список литературы}

1. Бурылин М.Ю., Малыхин С.Е., Галай Е.Ф. // Заводская лаборатория. Диагностика материалов. 2015. Т. 81. №4. С. 5-11.

2. Бурылин М.Ю., Малыхин С.Е., Галай Е.Ф. // Журн. аналит. химии. 2015. Т. 70. №4. С. 380-388.

Работа выполнена при финансовой поддержке Российского фонда фундаментальных исследований (гран № 1903-00181_a) с использованием научного оборудования ЦКП “Эколого-аналитический центр” Кубанского государственного университета. 